\title{
Identifikasi Pola Ruang Taman Setra Di Desa Singakerta, Kecamatan Ubud, Kabupaten Gianyar, Provinsi Bali
}

\author{
RIKA SILVIA ${ }^{1}$, A.A GEDE SUGIANTHARA ${ }^{1 *}$, \\ A.A. GEDE DALEM SUDARSANA ${ }^{1}$
}

1. Program Studi Arsitektur Pertamanan, Fakultas Pertanian, Universitas Udayana JI. PB Sudirman, Denpasar 80232 Bali

`E-mail: sugianthara@unud.ac.id

\section{ABSTRACT \\ Identification of The Graveyard Space Pattern at Singakerta Village, Ubud District, Gianyar Regency, Bali Province}

The background of this research is graveyard space pattern as Balinesse Traditional Garden very unique. The uniqueness of the pattern in every area is influenced by different customs in that area. This research is intented for identifying and describing the space pattern on every graveyard in Singakerta Village. The method which used survey with observation techniques, interview, distribution of questionnaires and literature review. Sampling technique used purposive sampling by choosing public figure on the six graveyard of Singakerta Village. The complements of hardscape in Graveyard Singakerta Village is prajapati, pamuhunan and grave area (genah mendem sawa) was found in every graveyard (100\%), wantilan in $70 \%$, the other building in $33 \%$. The complements of softscape were found 47 types of plant, kepah and bila found in Tunon and Singakerta, kepuh found in Tunon, Singakerta, Semana, pule and beringin found in Tunon, Singakerta, Demayu, ancak or bodi, bunut bulu, keduduk, kemiri only found in Singakerta, anggih and kepelan found in Kengetan. The conclution of this research is the space pattern of graveyard is influenced by age combination, clan, caste and amount of banjar, desa kala patra, desa mawa cara and meta-ethic conceps.

Keywords: identification, space pattern, singakerta graveyard, prajapati, pamuhunan, wantilan.

\section{Pendahuluan}

Keberadaan taman setra berperan sebagai Taman Tradisional Bali yang memiliki fungsi sebagai areal pelaksanaan upacara di Bali, khususnya upacara Pitra Yadnya. Taman setra juga memiliki fungsi sebagai ruang terbuka hijau, fungsi ekologis, estetika, dan fungsi sosial budaya masyarakat Bali. Taman Setra adalah bagian dari Taman Tradisional Bali karena memiliki pembagian ulu-teben dan Tri Mandala yang merupaka 
salah satu ciri khas Taman Tardisional Bali. Kebudayaan memiliki pengaruh unik bagi pola ruang taman setra yang berpengaruh langsung terhadap pemanfaatan taman setra bagi masyarakat Hindu. Tanah setra termasuk ke dalam tanah adat yang dikuasai oleh desa adat. Siahan (2010) menyatakan bahwa kecenderungan terjadinya penurunan kuantitas ruang publik, terutama ruang terbuka hijau pada 30 tahun terakhir. Ruang terbuka berupa pemakaman umum, sebagaimana pemanfaatan utamanya sebagai kuburan dengan berbagai kegiatan di dalamnya (Purwaningsih, 2009). Penurunan kuantitas ruang terbuka tidak terjadi pada setra.

Arsitektur Tradisional Bali mencerminkan pandangan meta-etika yang menbedakan ruang dalam oposisi biner antara sakral dan profan (ulu-teben) (Sukawati, 2017). Pola ruang taman setra di masing-masing desa pakraman memiliki elemen, bentuk dan ruang yang khas sesuai desa, kala, patra dan desa mawa cara. Taman setra secara umum memiliki pola ruang yang dibagi atas umur, kasta atau klan dan banjar. Taman setra di Singakerta mewakili pola ruang taman setra secara umum baik dibagi atas banjar, kasta atau klan dan umur. Total jumlah taman setra di Desa Singakerta adalah enam setra, dari ke enam taman setra masing-masing memiliki perbedaan. Atas dasar pemikiran dan hasil pra observasi itulah, dipandang perlu untuk meneliti mengenai identifikasi perbedaan pola ruang di tiap taman setra, sebagai sebuah taman atau lansekap tradisional Bali. Penelitian ini diharapkan dapat memberi gambaran terhadap pola ruang pemanfaatan setra, mampu menemukan penyebab perbedaan pola ruang guna pengelolaan taman setra yang efisien, serta untuk mendukung kebutuhan manusia akan lansekap tradisional Bali dan lingkungan taman setra. Rumusan masalah yang diangkat adalah bagaimana pola ruang dan pengaruh budaya atau adat terhadap taman setra yang ada di Desa Singakerta, Kecamatan Ubud, Kabupaten Gianyar, Provinsi Bali. Tujuan penelitian ini yaitu menganalisis serta mengidentifikasi penyebab perbedaan pola ruang taman setra di Desa Singakerta Kecamatan Ubud, Kabupaten Gianyar Provinsi Bali. Manfaat yang didapatkan dari penelitian ini adalah memberi sumbangan pemikiran bagi ilmu pengetahaun khususnya perkembangan ilmu arsitektur pertamanan terhadap informasi pola ruang taman setra, referensi bagi penelitian selanjutnya, serta dapat memberi masukan bagi masyarakat sebagai pembandingan ruang taman setra.

\section{Metode Penelitian}

\subsection{Tempat dan Waktu Penelitian}

Penelitian dilakukan di Desa Singakerta, Kecamatan Ubud, Kabupaten Gianyar, Provinsi Bali. Waktu penelitian direncanakan dalam jangka sembilan bulan, dimulai dari bulan Oktober 2016 sampai dengan bulan Juni 2017.

\subsection{Alat Penelitian}

Alat yang digunakan meliputi kamera handphone, perekam suara, komputer dan software yang digunakan untuk mengolah data berupa AutoCAD 2014, Adobe Photoshop CS6 dan Microsoft Office 2010 serta lembar pertanyaan kuesioner. 


\subsection{Metode Penelitian}

Penelitian ini menggunakan metode survei dengan teknik pengumpulan data melalui wawancara, penyebaran kuesioner, observasi lapangan dan studi kepustakaan. Teknik sampling untuk memperoleh data penelitian menggunakan teknik purposive sampling.

\subsection{Langkah Pengambilan Data}

Langkah pengambilan data yaitu: penentuan lokasi penelitian yaitu di Desa Singakerta, wawancara kepada bendesa adat, penyebaran kuesioner pada kelian adat serta tokoh-tokoh adat, serta pengamatan langsung ke lapangan, selanjutnya studi kepustakaan.

\subsection{Teknik Analisis Data}

Data yang diperoleh, selanjutnya dilakukan tabulasi dan di analisis secara deskriptif kualitatif sehingga didapatkan kesimpulan sesuai dengan fakta permasalahan di lapangan. Deskripsi data yang diperoleh akan disajikan dalam bentuk persentase (\%). Perhitungan persentase menggunakan rumus (Sudjana, 2001), yaitu:

$$
\mathrm{P}=\frac{f}{N} \times 100 \%
$$

Keterangan:

$P=$ persentase

$f=$ responden

$\mathrm{N}=$ total responden

\subsection{Batasan Penelitian}

Penelitian dilakukan di taman setra yang ada di Desa Singakerta, Kecamatan Ubud, Kabupaten Gianyar, Provinsi Bali. Hasil akhir yang diharapkan adalah mampu memberikan rekomendasi pengelolaan dan site plan ruang.

\section{Hasil dan Pembahasan}

\subsection{Gambaran Umum Desa Singakerta}

Desa Singakerta merupakan desa dinas yang berada di bawah Kecamatan Ubud Kabupaten Gianyar. Desa Singakerta terdiri atas lima desa adat atau desa pakraman, yaitu Desa Pakraman Tunon, Desa Pakraman Singakerta, Desa Pakraman Demayu, Desa Pakraman Tebongkang, dan Desa Pakraman Kengetan. Desa Singakerta memiliki luas wilayah $765 \mathrm{Ha}$, suhu udara rata-rata $32^{\circ}$ Celsius, curah hujan rata-rata $133 \mathrm{~mm}$ per tahun, serta merupakan daerah yang mempunyai ketinggian $170 \mathrm{~m}$ di atas permukaan laut (Badan Koordinasi Survei dan Pemetaan Nasional. 1999). 


\subsection{Hasil Penelitian}

Secara umum setiap desa pakraman memiliki satu taman setra, tetapi ada pula desa pakraman yang memiliki lebih dari satu. Demikian pula dengan taman setra di Desa Singakerta. Keberadaan taman setra biasanya sesuai dengan keberadaan Pura Kahyangan Tiga di masing-masing desa pakraman. Desa Singakerta terdiri atas lima desa pakraman dengan enam taman setra. Desa Pakraman Demayu merupakan desa pakraman yang memiliki dua taman setra. Taman setra merupakan bagian dari Pura Dalem. Pura yang berada di bagian Utara, Timur atau Timur Laut taman setra disebut Prajapati. Khusus pada Desa Pakraman Demayu memiliki dua Pura Dalem sehingga memiliki dua taman setra.

\subsubsection{Taman Setra Tunon}

Taman Setra Tunon seluas 0,511 Ha, dimiliki oleh Desa Pakraman Tunon, terdiri atas satu banjar adat. Masyarakat Tunon saat ini terbagi atas beberapa kasta dan klan yaitu, anak agung, gusti, dewe, pande dan pasek.

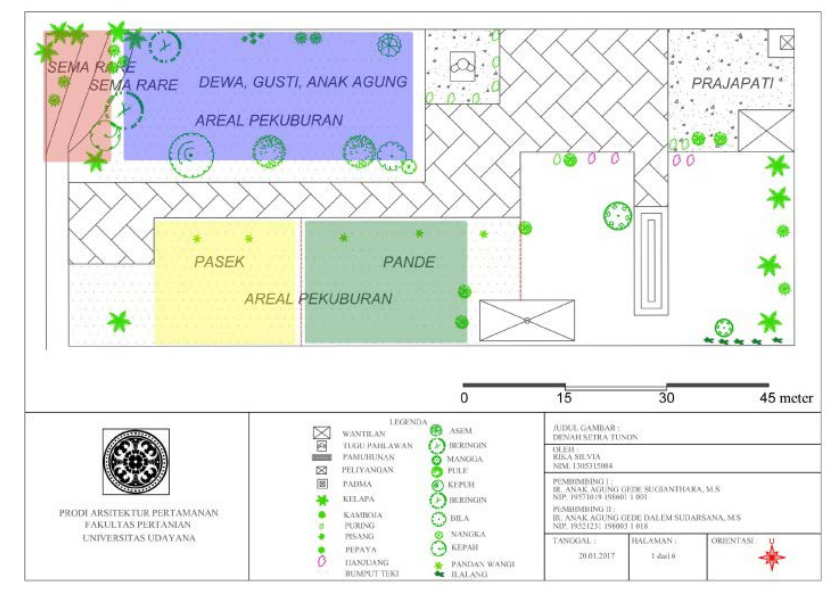

Gambar 1. Site Plan Pola Ruang Taman Setra Tunon

Taman setra dibagi atas dua ruang yaitu setra rare (kuburan anak-anak) dan setra umum (kuburan dewasa). Setra umum berada di tengah taman setra dan bagian ulu digunakan oleh masyarakat yang memiliki kasta ksatria (anak agung, gusti dan dewa) bagian teben digunakan oleh masyarakat pande dan pasek. Elemen keras yaitu prajapati, wantilan atau pesandekan, pamuhunan, setra umum, setra rare, perkerasan batu sikat dan paving, tempat pembuangan sampah. Elemen lunak kamboja (Plumeria rubra), puring (Cadiaeum variegatum), asem (Tamarindus indica), beringin (Ficus benyamina), bila (Crescentia cujeite), kelapa (Cocos nucitera), kepah (Sterculia foetida 'alba'), kepuh (Sterculia foetida), mangga (Mangifera indica), nangka (Arrocarpus integra), papaya (Carica papaya), pisang (Musa paradisiae), hanjuang (Cordyline terminalis), pandan wangi (Pandanus amaryllifolius), rumput teki (Cyperus rotundus L.), ilalang (Imperata cylindrica), dan pule (Alstonia scholaris $\mathrm{RBr}$ ). 


\subsubsection{Taman Setra Singakerta}

Taman Setra Singakerta merupakan taman setra dengan luas $0,815 \mathrm{Ha}$, dimiliki oleh Desa Pakraman Singakerta dengan enam banjar adat yaitu Katik Lantang, Lobong, Dauh Labak, Dangin Labak, Tengah dan Jukut Paku. Masyarakat Singakerta saat ini terbagi atas beberapa kasta dan klan yaitu ida bagus, anak agung, dewa, pande dan pasek.

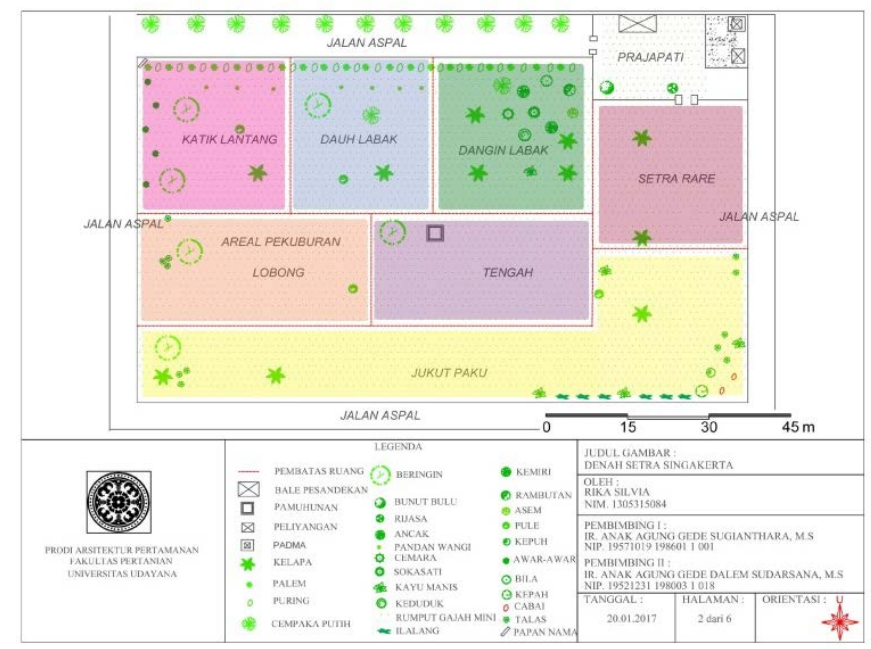

Gambar 2. Site Plan Pola Ruang Taman Setra Singakerta

Taman setra dibagi atas dua ruang yaitu setra rare dan setra umum. Setra rare digunakan bagi semua kasta atau klan yang ada. Setra umum memiliki pembagian ruang berdasarkan kombinasi kasta dan jumlah banjar. Bagian ulu digunakan oleh masyarakat dari banjar Dangin Labak, Dauh Labak dan Katik Lantang, bagian tengah digunakan oleh banjar Tengah dan Lobong, bagian teben digunakan oleh banjar Jukut Paku. Banjar Jukut Paku, Dauh Labak dan Dangin Labak, memiliki kasta brahmana dan memiliki tempat khusus di ulu bersama brahmana dari banjar Dangin Labak. Elemen keras yaitu prajapati, wantilan atau pesandekan, pamuhunan, plang nama, setra umum, setra rare, perkerasan aspal, dan tempat pembuangan sampah. Elemen lunak yaitu bunut bulu (Ficus drupacea Thunb), rijasa (Elaeocarous grandifloras Smith), rumput gajah mini (Pennisetum purpureum), asem, awar-awar (Ficus septica), bodi (Ficus rumphii Bl), beringin, bila, cabai (Capsicum annuum), ilalang, kayu manis (Sauropus androggynus), keduduk (Melastoma efina D Don), kemiri (Aleurits moluccana), kelapa, kepah, kepuh, majegau (Dusoxylum densiflorum), pandan wangi, palem (Areca catechu), puring, pule, rambutan (Nephelium sp.), sokasati, dan talas (Colocasia esculenta).

\subsubsection{Taman Setra Demayu}

Taman Setra Demayu merupakan taman setra dengan luas 0,700 Ha, dimiliki oleh Desa Pakraman Demayu dengan lima banjar adat yaitu Banjar Tewel, Batuh, Buduk, Lodtunduh dan Semana. Pembagian ruang dalam taman setra dibagi atas banjar dan kasta atau klan. Pembagian banjar, sesuai jumlah banjar yang ada di Desa Pakraman 
Demayu, pembagian ruang bagi kasta ksatria dalam satu banjar sesuai posisi banjar dan klan senggu yang ada di Banjar Lodtunduh memiliki ruang tersendiri.

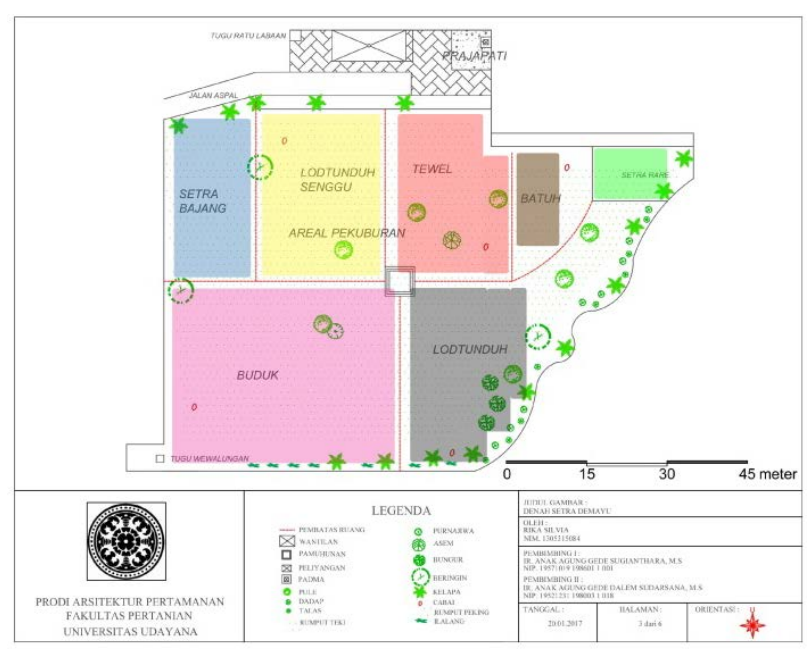

Gambar 3. Site Plan Pola Ruang Taman Setra Demayu

Taman setra dibagi atas tiga ruang yaitu setra rare (kuburan anak-anak), bajang (remaja) dan umum (dewasa). Setra rare digunakan bagi semua kasta atau klan dan banjar yang ada. Setra bajang digunakan bagi semua kasta atau klan dan banjar yang ada. Setra umum bagian ulu digunakan oleh masyarakat Banjar Tewel, bagian tengah digunakan Banjar Batuh dan Banjar Lodtunduh klan senggu, teben digunakan oleh masyarakat Banjar Buduk dan Lodtunduh. Khusus brahmana dari Banjar Batuh memiliki taman setra tersendiri. Elemen keras yaitu prajapati, wantilan pamuhunan, setra dewasa, setra rare, perkerasan aspal dan paving, tempat pembuangan sampah. Elemen lunak yaitu puring, asem, beringin, bungur (Lagerstroemia speciosa), cabai, dadap (Erythina variegata), ilalang, pule, kelapa, rumput teki, talas, dan purnajiwa (Euchresta horsfildii Benn).

\subsubsection{Taman Setra Semana}

Taman Setra Semana merupakan taman setra dengan luas 0,337 Ha. Taman Setra Semana memiliki pembagian ruang dibagi berdasarkan kasta atau klan dan umur dengan kasta weisya dan sudra dalam masyarakat Semana. Pola ruang dibagi atas dua yaitu setra rare dan umum, untuk setra umum bagian ulu digunakan oleh weisya dan teben digunakan oleh sudra.

Elemen keras yaitu prajapati, pamuhunan, setra umum, setra rare, perkerasan paving, tempat pembuangan sampah. Elemen lunak yaitu kamboja, asem, dadap, kelapa, kepuh, mangga, talas, rumput gajah mini, dan ialalang. 


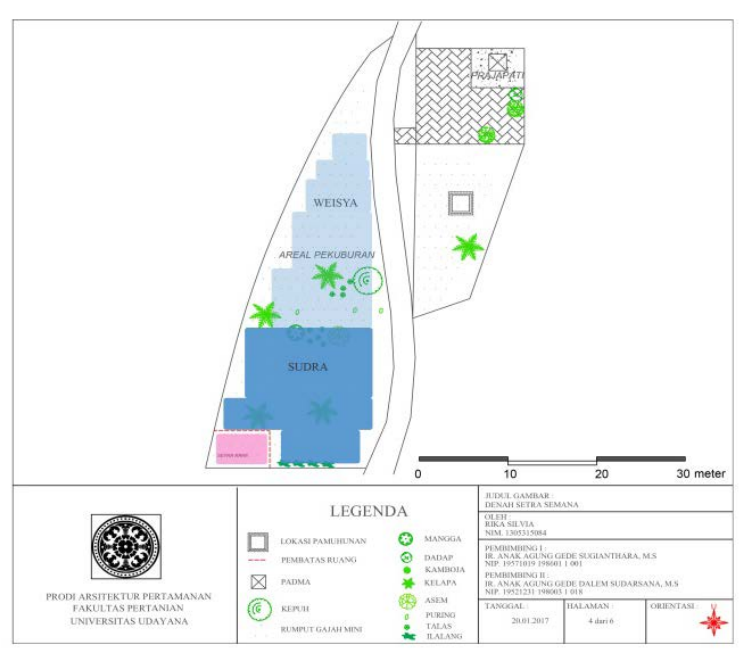

Gambar 4. Site Plan Pola Ruang Taman Setra Semana

\subsubsection{Taman Setra Tebongkang}

Taman Setra Tebongkang merupakan taman setra dengan luas 0,147 Ha, dimiliki oleh Desa Pakraman Tebongkang dengan satu banjar adat. Masyarakat Tebongkang saat ini terbagi atas beberapa klan yaitu dewa, sang dan pasek.

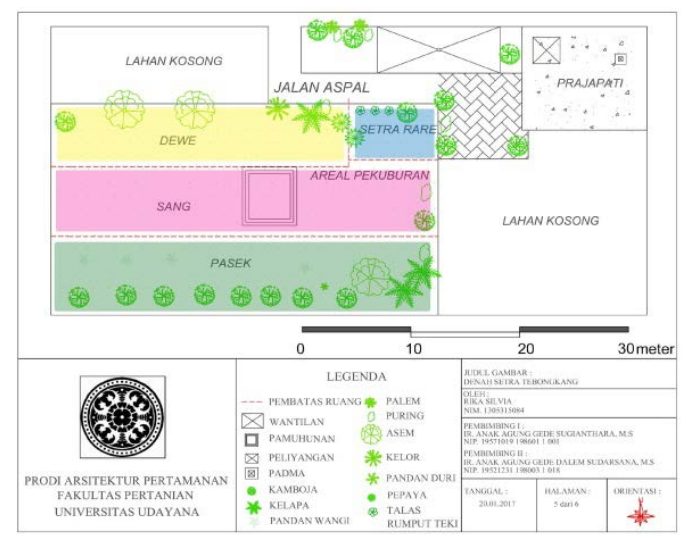

Gambar 5. Site Plan Pola Ruang Taman Setra Tebongkang

Taman setra dibagi atas dua ruang yaitu setra rare dan setra umum. Setra rare digunakan bagi semua kasta atau klan yang ada. Setra umum bagian ulu digunakan oleh masyarakat dengan klan dewa, bagian tengah digunakan oleh masyarakat klan sang, dan teben digunakan oleh masyarakat klan pasek. Elemen keras yaitu prajapati, wantilan, pamuhunan, setra dewasa, setra rare, perkerasan aspal dan paving, serta tempat pembuangan sampah. Elemen lunak yaitu kamboja, asem, kelapa, kelor (Moringa oleifera), palem, pandan duri, pandan wangi, pepaya, puring, rumput teki, ilalang, dan talas. 


\subsubsection{Taman Setra Kengetan}

Taman Setra Kengetan memiliki luas 0,474 are, dimiliki oleh Desa Pakraman Kengetan dengan satu banjar adat. Taman Setra Kengetan telah memiliki pembagian lokasi yang baku, yaitu dibagi berdasarkan klan dan kasta. Masyarakat Kengetan memiliki kasta brahmana, gusti, dewa, klan Pasek Dangke, Pasek Pulasari, Pasek Gel - Gel, klan arya, klan senggu, dan klan peling.

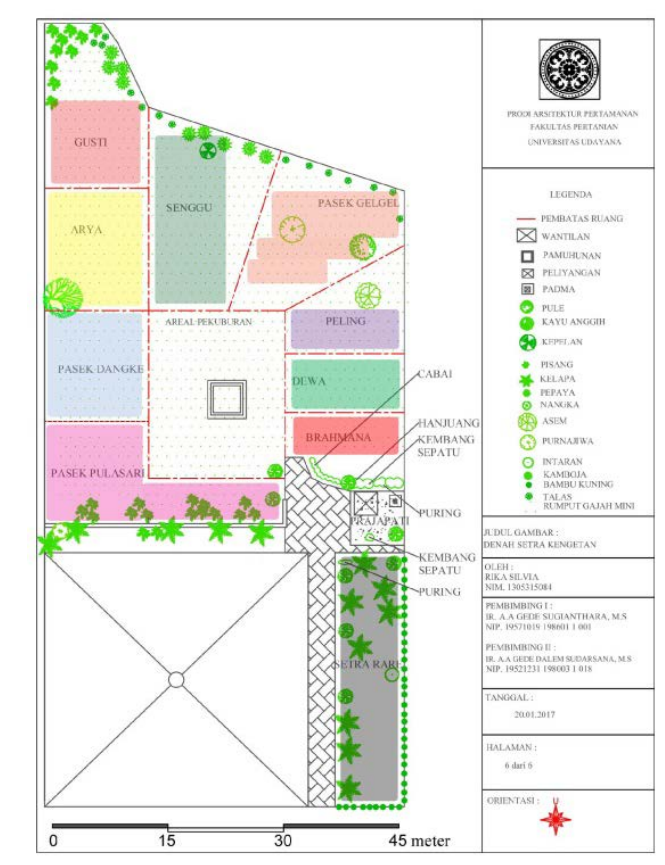

Gambar 6. Site Plan Pola Ruang Taman Setra Kengetan

Taman setra dibagi atas dua ruang yaitu setra rare dan setra umum. Setra umum bagian ulu digunakan oleh kasta brahmana, dewa dan klan Pasek Gel - gel, bagian tengah digunakan oleh klan gusti, senggu, Pasek Pulasari, dan teben digunakan Pasek Dangke. Elemen keras yaitu prajapati, wantilan, pamuhunan, setra umum, setra rare, perkerasan paving dan batu koral, serta tempat pembuangan sampah. Elemen lunak yaitu kamboja, kembang sepatu (Hibiscus rosachinensis), asem, bambu kuning (Bambusa vulagaris), cabai, hanjuang, intaran (Azadiractha indica), kamboja, kayu anggih, kelapa, kepelan (Stelechocarpus burahol), pisang, pepaya, puring, purnajiwa, pule, rumput gajah mini, talas, nangka, dan rumput gajah mini.

\subsection{Pembahasan}

\subsubsection{Pola Pembagian Ruang Taman Setra di Desa Singakerta}

Pola pembagian ruang ke enam taman setra bervariasi, dapat dilihat pada Tabel 1. 
Tabel 1. Pola Pembagian Ruang Taman Setra Desa Singakerta

\begin{tabular}{|c|c|c|c|c|c|c|c|c|c|c|c|c|c|c|}
\hline \multirow{3}{*}{ No } & \multirow{3}{*}{$\begin{array}{c}\text { Nama Taman } \\
\text { Setra }\end{array}$} & \multicolumn{13}{|c|}{ Pola Ruang } \\
\hline & & \multicolumn{3}{|c|}{$\begin{array}{c}\text { Berdasarkan } \\
\text { Umur }\end{array}$} & \multicolumn{4}{|c|}{$\begin{array}{c}\text { Berdasarkan Klan atau } \\
\text { Kasta }\end{array}$} & \multicolumn{6}{|c|}{ Berdasarkan Jumlah Banjar } \\
\hline & & $\mathrm{R}$ & $\mathrm{B}$ & $\mathrm{U}$ & BR & $\mathrm{KS}$ & WS & $\mathrm{SU}$ & 1 & 2 & 3 & 4 & 5 & 6 \\
\hline 1 & Tunon & $Y a$ & Talk & Ya & Tale & Ya & Ya & Ya & Ya & Telk & Telk & Telk & Telk & Tak \\
\hline 2 & Singakerta & $\mathrm{Ya}$ & Tak & $\mathrm{Ya}$ & $\mathrm{Ya}$ & $\mathrm{Ya}$ & $\mathrm{Ya}$ & $\mathrm{Ya}$ & Tak & Talk & Tak & Talk & Tak & $\mathrm{Ya}$ \\
\hline 3 & Demayu & $\mathrm{Ya}$ & $\mathrm{Ya}$ & $\mathrm{Ya}$ & $\mathrm{Ya}$ & $\mathrm{Ya}$ & $\mathrm{Ya}$ & Tase & Talk & Telk & Tak & $\mathrm{Ya}$ & Tak & Tak \\
\hline 4 & Semana & $\mathrm{Ya}$ & Talk & $\mathrm{Ya}$ & Tak & Talk & $\mathrm{Ya}$ & $\mathrm{Ya}$ & $\mathrm{Ya}$ & Talk & Talk & Tak & Tak & Tak \\
\hline 5 & Tebongkang & $\mathrm{Ya}$ & Talk & $\mathrm{Ya}$ & Tak & $\mathrm{Ya}$ & $\mathrm{Ya}$ & $\mathrm{Ya}$ & $\mathrm{Ya}$ & Talk & Tak & Tak & Tak & Tak \\
\hline 6 & Kengetan & $\mathrm{Ya}$ & Talk & $\mathrm{Ya}$ & $\mathrm{Ya}$ & $\mathrm{Ya}$ & $\mathrm{Ya}$ & $\mathrm{Ya}$ & $\mathrm{Ya}$ & Talk & Tak & Tak & Tak & Tak \\
\hline
\end{tabular}

Keterangan :

$\mathrm{R}=$ Setra rare, $\mathrm{B}=$ Setra bajang, $\mathrm{U}=$ Setra Umum, BR = Brahmana, KS = Ksatria, WS = Weisya, SU = Sudra Tdk = Tidak.

Pembagian tata ruangnya di bagi berdasarkan umur (Tabel 1), tetapi Taman Setra Demayu memiliki ke khasan karena memiliki setra bajang (kuburan remaja). Pada Arsitektur Tradisional Bali terdapat pandangan meta-etika yang membedakan ruang dalam oposisi biner antara sakral dan profan (ulu-teben) (Sukawati,2017). Sistem kasta dan klan menganut sistem meta-etika dalam sistem pinget serta memiliki peran penting juga dalam pembagian ruang taman setra. Sistem ulu-teben dipengaruhi pembagian berdasarkan kasta masyarakat. Ruang-ruang tersebut dibagi dengan sistem pinget dan kasta sesuai budaya serta adat, blok-blok area yang akan digunakan sudah ada dan saling mengetahui antar masyarakat.

Khusus pada Taman Setra Kengetan pembagian ruang berdasarkan klan dan kasta yang sudah baku dan kompleks, bahkan untuk klan pasek memiliki areal tersendiri. Taman Setra Demayu selain memiliki pembagian ruang berdasarkan banjar dan klan, khusus pada Banjar Adat Batuh masyarakatnya ada yang berkasta brahmana, kasta tersebut memiliki taman setra tersendiri. Berdasarkan hasil penelitian disimpulkan bahwa pola ruang taman setra di Desa Singakerta dipengaruhi oleh budaya dan adat dari umur, kasta atau klan, dan jumlah banjar masyarakatnya. Untuk lebih jelas posisi masing-masing taman setra di gambarkan dalam satu peta, berupa denah lokasi ke enam taman setra di Desa Singakerta, dapat dilihat pada Gambar 5. di bawah ini. 


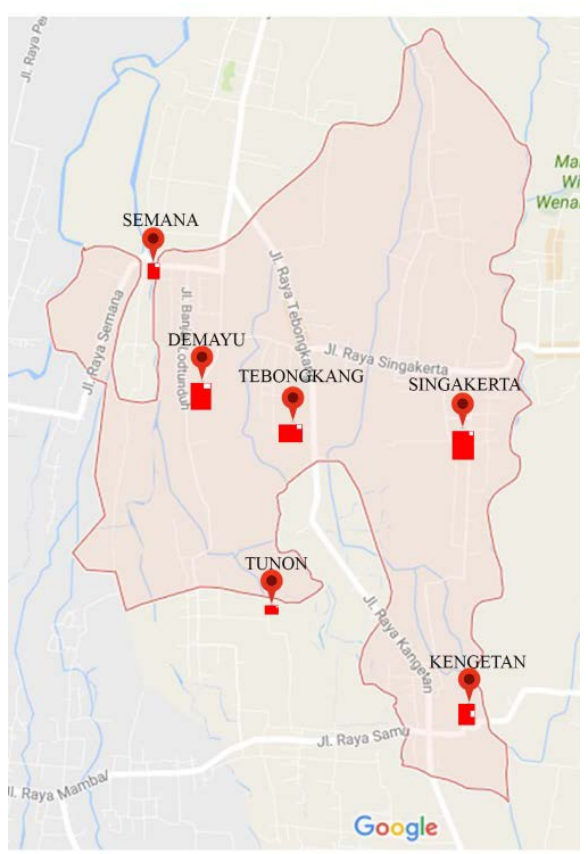

Gambar 5. Denah Site Plan Pola Ruang (Sumber: Google Earth, 2017)

\subsubsection{Elemen Keras Taman Setra di Desa Singakerta.}

Taman setra memiliki elemen pokok yang wajib ada yaitu prajapati, wantilan atau pesandekan, pintu gerbang atau cangkem setra, pemuhunan, setra umum, setra rare, dan tempat pembuangan sampah. Penelitian menunjukkan terdapat elemen tambahan dalam taman setra yaitu elemen keras yang ada di Tunon dan Singakerta berupa tugu pahlawan dan plang nama. Elemen keras taman setra di Desa Singakerta diidentifikasi sebagai berikut: prajapati, pamuhunan dan areal perkuburan terdapat di semua taman setra (100\%), wantilan sebanyak $70 \%$, serta tembok pembatas dan pintu gerbang atau cangkem setra belum ada di semua taman setra. Taman Setra Demayu dan Semana pamuhunannya belum permanen hanya berupa gundukan tanah. Taman Setra Singkerta tidak memiliki wantilan, melainkan balai pesandekan yang berada di areal jaba tengah prajapati.

Prajapati yang ada dalam taman setra masing-masing dilengkapi dengan beberapa bangunan seperti padmaasari, kecuali di Taman Setra Singakerta bangunannya berupa padmasana. Bangunan peliyangan, tembok penyengker dan candi bentar terdapat di semua prajapati kecuali di Taman Setra Semana. Candi bentar bagian luar dihiasi patung di bagian kiri dan kanan dengan jenis patung bervariasi seperti patung raksasa, Kalika dan Sang Suratma. Taman setra juga dihiasi lampu taman dengan jumlah mulai dari tiga sampai lima lampu. Perkerasan dalam bangunan prajapati bagian dalam berupa batu sikat, paving dan beton, bagian luar beton dan paving. Konsep meta-etika yang membedakan ruang Utama Mandala, Madya Mandala dan Nista Mandala mempengaruhi letak prajapati. Penelitian menunjukkan lima dari enam prajapati berada di Utama Mandala yaitu Timur Laut (Ersania), kecuali di Kengetan berada di Timur taman setra. 


\subsubsection{Elemen Lunak Taman Setra di Desa Singakerta.}

Tanaman yang ada di taman setra sebanyak 47 jenis, terdiri atas 30 jenis pohon, sembilan jenis perdu, empat jenis semak dan empat jenis penutup tanah. Beberapa tanaman juga telah ditentukan sebagai elemen pokok yang harus ada karena memiliki nilai filosofis di dalam setra dan menjadi tanaman langka atau sulit dijumpai lagi. Areal taman setra ditanami dengan tanaman yang memberi nuansa magis antara lain kepah (Sterculia foetida 'alba'), kepuh (Sterculia foetida), pule (Alstonia scholaris RBr), bunut (Ficus drupacea Thunb), beringin (Ficus benyamina), kemiri (Aleurits moluccana), bila (Crescentia cujeite), asem (Tamarindus indica) dan majegau (Dusoxylum densiflorum) (Sardiana, dkk. 2012). Tanaman kepah (Sterculia foetida 'alba') dan bila (Crescentia cujeite) hanya ditemukan di Tunon dan Singakerta, tanaman kepuh (Sterculia foetida) hanya ditemukan di Tunon, Singakerta dan Semana, tanaman pule (Alstonia scholaris $\mathrm{RBr}$ ) dan beringin (Ficus benyamina), hanya ditemukan di Tunon, Singakerta dan Demayu. Tanaman lain yang mulai langka hanya ditemukan di Taman Setra Singakerta yaitu tanaman ancak atau bodi (Ficus rumphii BI), bunut bulu (Ficus drupacea Thunb), keduduk (Melastoma efina D Don), kemiri (Aleurits moluccana), rijasa (Elaeocarous grandifloras Smith) dan majegau (Dusoxylum densiflorum). Tanaman kayu anggih dan kepelan (Stelechocarpus burahol) hanya terdapat dalam Taman Setra Kengetan.

Keadaan di atas sangat disayangkan, tanaman tersebut seharusnya ada di setiap taman setra karena memiliki nilai filosofis, seperti pohon kepah dan kepuh adalah tanaman yang dikatakan sebagai lambang laki-laki dan perempuan, diyakini sebagai tempat anak buah Dewi Durga, pule adalah tanaman yang diyakini sebagai tempat tinggal dan singgahnya para pengikut Dewi Durga, asam adalah tanaman yang diyakini sebagai makanan atma, majegau adalah tanaman yang diyakini sebagai tempat persembahyangan bagi para roh, bila adalah tanaman yang diyakini sebagai tempat pendidikan para atma sesuai Lontar Ajijanantaka.

Tanaman di atas memiliki nilai magis dan filosofis serta menjadi elemen pokok yang harus ada dalam taman setra, selain itu terdapat tanaman lain sebagai elemen tambahan yang memiliki fungsi penyerap $\mathrm{CO} 2$ dan menghasilkan 02 , memiliki tajuk yang lebar sehingga mampu menambah kesejukan bagi lingkungan sekitar.

\section{Simpulan dan Saran}

\subsection{Simpulan}

Pola ruang taman setra di Desa Singakerta dipengaruhi budaya dan adat sesuai konsep ruang berdasarkan tiga penyebab utama yaitu umur, kasta atau klan, dan jumlah banjar. Pembagian ruang dipengaruhi pula oleh konsep Arsitektur Tradisional Bali yaitu meta-etika dan kombinasi dari ketiga konsep tersebut serta desa kala patra dan desa mawa cara di masing-masing desa pakraman. Elemen keras yang ada di enam Taman Setra Singakerta diidentifikasi sebagai berikut: prajapati, pamuhunan dan area perkuburan (genah mendem sawa) 100\%, wantilan atau pesandekan 70\%. Tugu pahlawan terdapat pada Taman Setra Tunon serta plang nama pada Taman Setra Singakerta. Semua taman setra di Desa Singakerta belum memiliki tembok pembatas (penyengker), pintu gerbang 
atau cangkem setra. Elemen lunak sebanyak 47 jenis, terdiri atas 30 jenis pohon, sembilan jenis perdu, empat jenis semak dan empat jenis penutup tanah. Elemen lunak seperti tanaman kepah (Sterculia foetida 'alba'), dan bila (Crescentia cujeite) hanya ditemukan di dua taman setra, tanaman kepuh (Sterculia foetida) hanya ditemukan di tiga taman setra, pule (Alstonia scholaris RBr) dan beringin (Ficus benyamina) hanya ditemukan di tiga taman setra yaitu di Tunon, Singakerta, Dumayu, tanaman asem (Tamarindus indica) dapat ditemukan di semua taman setra. Tanaman ancak atau bodi (Ficus rumphii Bl), bunut bulu (Ficus drupacea Thunb), keduduk (Melastoma efina D Don), kemiri (Aleurits moluccana), rijasa (Elaeocarous grandifloras Smith) dan majegau (Dusoxylum densifforum) hanya ditemukan di Taman Setra Singakerta. Tanaman kayu anggih dan kepelan (Stelechocarpus burahol) hanya terdapat dalam Taman Setra Kengetan, beberapa di antaranya ada yang mulai langka keberadaanya dan perlu dilestarikan.

\subsection{Saran}

Perlu dilakukan penelitian lebih lanjut di tempat lain sehingga didapat variasi pola ruang taman setra yang lebih lengkap dan menyeluruh, serta masing-masing desa pakraman sebagai pihak pengelola taman setra sekaligus sebagai pihak pengguna taman setra disarankan lebih memperhatikan kelengkapan dan perawatan elemen baik elemen keras dan elemen lunak di dalam taman setra. Kelengkapan elemen penting demi menunjang keberlangsungan pemanfaatan taman setra sebagai Taman Tradisional Bali.

\section{Daftar Pustaka}

Badan Koordinasi Survei dan Pemetaan Nasional. 1999. Peta Rupabumi Digital Indonesia Lembar 1707-343 Gianyar. Dilaksanakan oleh Blom Narcon Cooperation. Bandung.

Google Earth. 2017. Explore, Search and Discover. Available online at: www.earth.google.com. (accesed 3 April 2017).

Purwaningsih, F. 2009. Perencanaan Dan Perancangan Arsitektur Memorial Park \& Funeral Homes Di Mojosongo Surakarta. Skripsi (Tidak dipublikasikan). Teknik Arsitektur Fakultas Teknik Universitas Muhammadiyah, Surakarta.

Sardiana, I. K. ; N. M Wiasti; I. N. Wardi 2012. Etnobotani Bali. Udayana University Press. Denpasar. 213 hal.

Siahan, J. 2010. Ruang Publik : Antara Harapan dan Kenyataan, Buletin Tata Ruang, Edisi IV (Juni-Juli 2010). Badan Koordinasi Penataan Ruang Nasional. Hal 11-16.

Sudjana, D. 2001. Metode Statiska. Tarsito. Bandung. 192 hal.

Sukawati, Tjokorda Oka Artha Ardhana. 2017. Implementasi Desain Taman Tradisional Bali Dalam Pembangunan Pariwisata di Bali. Seminar Keilmuan Prodi Arsitektur Lansekap, Fakultas Pertanian, Universitas Udayana. Denpasar. Halaman 3-5. 